\title{
Northeastern Journal of Agricultural and Resource Economics
}

Food Safety Policy Fights: A U.S. Perspective/Julie A. Caswell

Food Safety Issues in Canada/Ian R. Sutherland

The Canada-U.S. Free Trade Agreement and Canada's Agri-Food Industries/Alan M. Rugman and Andrew Anderson

The U.S.-Canada Free Trade Agreement and Agriculture: One Year Later/Carol Goodloe

The Profitability of Sustainable Agriculture on a Representative Grain Farm in the Mid-Atlantic Region, 1981-89/James C. Hanson, Dale M. Johnson, Steven E. Peters, and Rhonda R. Janke

Investment Behavior and Energy Conservation/Eddy L. LaDue, Lynn H. Miller, and Joseph H.

Kwiatkowski

Conjoint Analysis of Deer Hunting/John Mackenzie

Assessing the Importance of Apple Attributes: An Agricultural Application of Conjoint Analysis /

Alberto B. Manalo

Dichotomous-Choice, Contingent-Valuation Questions: Functional Form Is Important/Kevin J. Boyle Modeling State Agriculture: An Application and Some Implications/Olugbenga Onafowora, Gerard D'Souza, and Dale Colyer

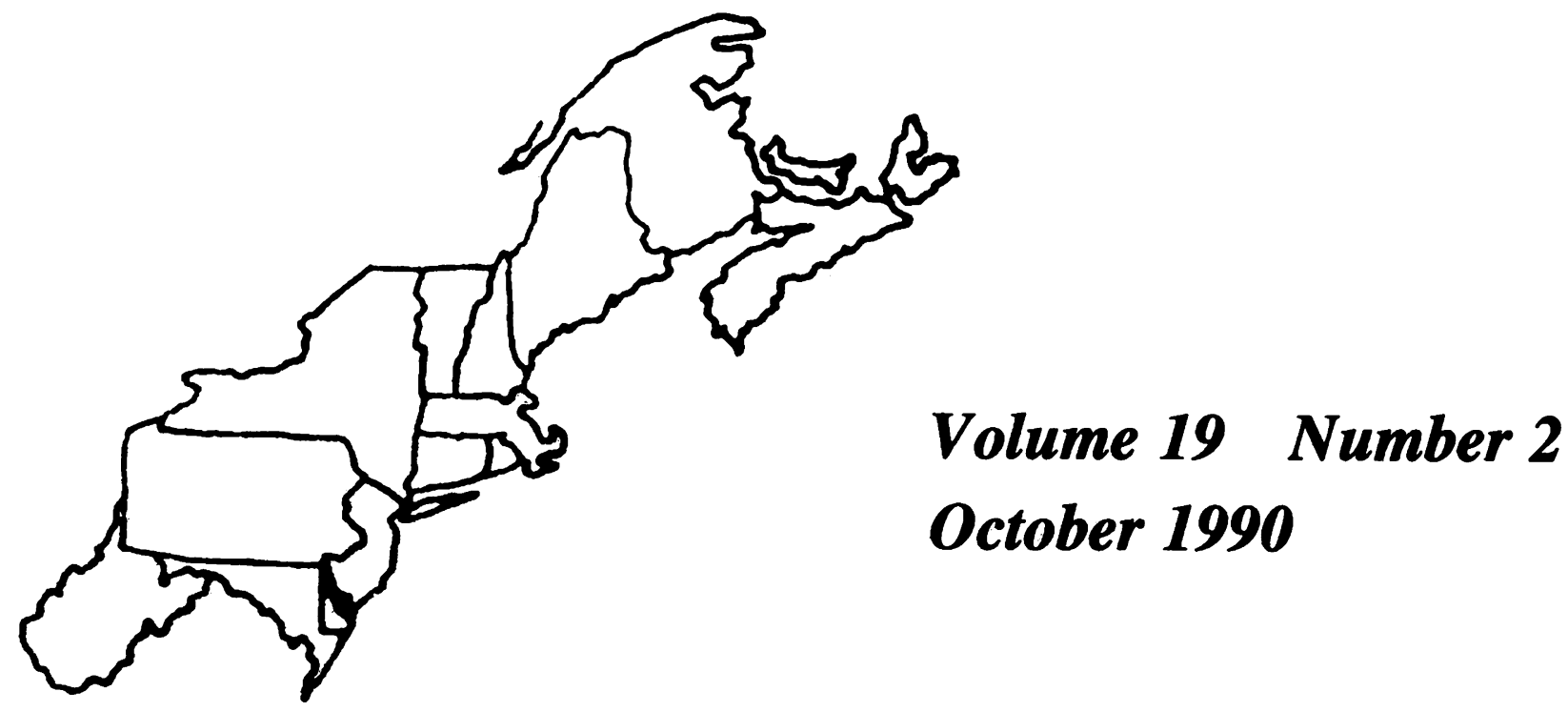




\section{NORTHEASTERN JOURNAL OF AGRICULTURAL AND RESOURCE ECONOMICS VOLUME 19, NUMBER 2, OCTOBER 1990}

Loren W. Tauer, Editor

EDITORIAL BOARD

Anwarul Hoque, ERS, USDA (1990)

David Lee, Cornell (1990)

C. Edwin Young, ERS, USDA (1990)

Conrado Gempesaw, Delaware (1991)

Rigoberto Lopez, Connecticut (1991)
James Opaluch, Rhode Island (1991)

Boris Bravo-Ureta, Connecticut (1992)

Michele Marra, Maine (1992)

Spiro Stefanou, Pennsylvania (1992)
PRESIDENT

PRESIDENT-ELECT

SECRETARY-TREASURER

\section{ASSOCIATION OFFICERS}

Billy V. Lessley, Maryland

Olan D. Forker, Cornell

Steven E. Hastings, Delaware

\section{EXECUTIVE COMMITTEE}

Geoffrey Allen, Massachusetts

Lorna Aldrich, USDA

Bradley Cilley, C.R. Bard, Inc.

Donn Derr, Rutgers

Olan Forker, Cornell

John Halstead, New Hampshire

Steven Hastings, Delaware
Bill Lessley, Maryland

John Mackenzie, Delaware

Michele Marra, Maine

James Opaluch, Rhode Island

Loren Tauer, Cornell

Cleve Willis, Massachusetts
The Northeastern Journal of Agricultural and Resource Economics (ISSN 0899-367X) is the official publication of the Northeastern Agricultural and Resource Economics Association (NAREA). The purpose of the Journal is to foster and disseminate professional thought and literature relating to the economics of agriculture, natural resources, and community development. It is published in April and October. In addition to normal refereed articles, it also publishes invited papers presented at the annual meetings of the NAREA as well as abstracts of selected papers presented at those meetings. It periodically calls for articles written on a specific topic. Membership in the NAREA is open to all persons having an interest in agricultural and resource economics. Membership dues include subscription to the Journal and are $\$ 15.00$ per year regular and \$5.00 per year student. All other subscriptions are $\$ 15.00$ per year. Single copy prices are $\$ 7.50$ per issue.
Address all manuscripts and editorial material to:

\section{Loren Tauer \\ 452 Warren Hall}

Cornell University

Ithaca, NY 14853

Address requests for membership, subscriptions, and changes of address to:

Steven E. Hastings

Dept. of Food and Resource Economics

University of Delaware

Newark, DE 19717 
Invited Papers

\section{Contents}

Food Safety Policy Fights: A U.S. Perspective/Julie A. Caswell ................... 59

Food Safety Issues in Canada/Ian $R$. Sutherland $\ldots \ldots \ldots \ldots \ldots \ldots \ldots \ldots \ldots \ldots \ldots \ldots \ldots \ldots \ldots \ldots \ldots \ldots \ldots$

The Canada-U.S. Free Trade Agreement and Canada's Agri-Food Industries/Alan M.

Rugman and Andrew Anderson ........................................... 70

The U.S.-Canada Free Trade Agreement and Agriculture: One Year Later/Carol Goodloe ... 80

Articles

The Profitability of Sustainable Agriculture on a Representative Grain Farm in the Mid-

Atlantic Region, 1981-89/James C. Hanson, Dale M. Johnson, Steven E. Peters, and

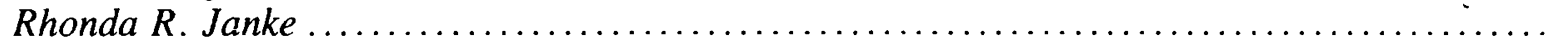

Investment Behavior and Energy Conservation/Eddy L. LaDue, Lynn H. Miller, and

Joseph H. Kwiatkowski.

Conjoint Analysis of Deer Hunting/John Mackenzie .

Assessing the Importance of Apple Attributes: An Agricultural Application of Conjoint

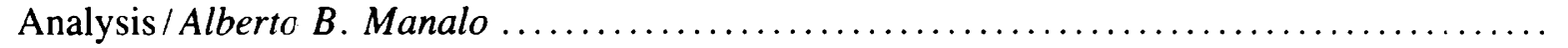

Dichotomous-Choice, Contingent-Valuation Questions: Functional Form Is Important/

Kevin J. Boyle.

Modeling State Agriculture: An Application and Some Implications/Olugbenga Onafowora,

Gerard D'Souza, and Dale Colyer

Abstracts of Organized Symposia and Selected Papers

Master's Thesis Award Abstracts

Distinguished Member Awards

Presidents, 1955-90

Minutes of Business Meeting .

NJARE Reviewers, August 1989 to September 1990. 